\title{
In vitro evaluation of additives allowed for high strength concrete (HSC) and foam concrete
}

\section{Yüksek mukavemetli beton (HSC) ve köpük beton için izin verilen katkıların in vitro değerlendirilmesi}

\author{
Hadi FAGHIHMALEKI ${ }^{*}$, Faezeh NEJATI ${ }^{1}$, Hossien MASOUMI ${ }^{1}$ \\ ${ }^{1}$ Department of Civil Engineering, Ayandegan Institute of Higher Education, Tonekabon, Iran. \\ h.faghihmaleki@gmail.com, hossein.masoumi@unsw.edu.au
}

\begin{abstract}
Thanks to significant advances in materials science, researchers have managed to fabricate and develop different types of concrete proportional to application of new concrete technologies, such as high strength concrete (HSC) and foam concrete. The current paper presents the results of in experimental studies on foam concrete and its application. In addition, the effect of various parameters such as cement content, Water/Cement ratio as well as application of additives has been studied in mix design. In HSC, interaction between concrete constituent materials plays an important role in mechanical properties and compressive strength of concrete. Therefore, an appropriate understanding of these factors helps us select the suitable type and amount of materials in order to make a concrete with desirable behavior and strength. The methods and theoretical procedures used in the study is based on the ACI codes. This study aims to investigate the effect of using Micro Silica and plasticizer on strength of HSC. Based on the obtained results, the optimum percentage used for concrete mix design and positive effects of these materials on concrete property were confirmed.
\end{abstract}

Keywords: Foam concrete, HSC, Micro silica, Plasticizer, Fly ash, Compressive strength

\section{Introduction}

In today's advanced world and with respect to advances in various fields, concrete industry has also undergone major improvements including production of foam concrete which reduces the dead load of a concrete structure, mitigates earthquake-induced force to the structure and leads to lower debris weight after structure collapse [1]-[3]. Based on its specific properties, foam concrete has different applications distinguished in terms of its special weight and compressive strength [4]. Lightweight aerated concrete became popular in the US, Netherlands and later in Germany since 1923. Today, application of light weight concrete (foam concrete) has become popular across different countries as a light and costeffective material [5]. However, using of the lightweight concrete has been used in the seismic regions if their seismic code has been recommended that it can be used. Arman et al. [6], conducted a comprehensive study on effective parameters and properties in foam concrete (such as high strength-toweight ratio and low density); moreover, they presented a comprehensive view about possible equipment to produce foam concrete in industry. Jiang et al. [7] conducted a study on high-porosity foamed concretes made by ordinary Portland cement. In their study, they examined all the effective parameters in such concretes and determined optimum value
Öz

Malzeme bilimindeki önemli ilerlemeler sayesinde araștırmacllar, yüksek mukavemetli beton (HSC) ve köpük beton gibi yeni beton teknolojilerinin uygulanmasina orantıl olarak farklı beton tipleri üretip geliştirmeyi başardılar. Bu yazıda köpük beton ve uygulamaları üzerine deneysel çalışmaların sonuçları sunulmaktadır. Ayrıca çimento içeriği, su / çimento oranı ve katkı maddeleri gibi çeşitli parametrelerin etkisi karışım tasarımında incelenmiştir. HSC'de beton kurucu maddeler arasındaki etkilesim, betonun mekanik özelliklerinde ve basınç dayanımında önemli rol oynamaktadır. Bu nedenle, bu faktörlerin uygun bir șekilde anlașılması, istenen davranıș ve dayanıklılı̆̆ı olan bir betonun yapılması için uygun tür ve miktarda malzemeyi seçmemize yardımcı olur. Çalıșmada kullanılan yöntemler ve teorik prosedürler ACI kodlarına dayanmaktadır. Bu çalıșma, HSC'nin mukavemetine Micro Silica ve plastikleștiricilerin kullanmasının etkisini araștırmayı amaçlamaktadır. Elde edilen sonuçlara göre, beton karışımı tasarımı için kullanılan optimum oran ve bu malzemelerin beton mülkiyet üzerindeki olumlu etkileri doğrulanmıştır.

Anahtar kelimeler: Köpük beton, HSC, Mikro silika, Plastifiyan, Uçucu kül, Basınç mukavemeti

of each parameter. Guo et al. [8], performed a theoretical and experimental study on non-linear, mechanical response of foamed concrete under non-axial compressive load over a wide range of temperatures and strain rates. They concluded that non-linear deformation behavior of foamed concrete undergoes various changes relative to changes in density and temperature.

The current research presents an experimental study in production of foam concrete, whereby ideal percentages for mix design of this concrete type are introduced; in addition, "do's and don'ts" to produce a high-quality foam concrete are presented based on the experimental results.

Nowadays, along with the progress in construction industry, the importance of High Strength Concretes (HSC) is more evident than before. Mousa [9] conducted an experimental program in order to investigate the flexural behaviour of concrete beams (HSC) with variable length of tension reinforcement lap splice. Results show that by introducing an appropriate amount and distribution of transverse reinforcement, a satisfactory ductility response can be obtained. EL-Azab and Mohamed [10], examined the effect of tension lap slice on the behavior of high strength concrete (HSC) beams. The research involved tests on sixteen simplysupported beams of $1800 \mathrm{~mm}$ span, $200 \mathrm{~mm}$ width and 400 
mm thickness made of HSC. Finally, properties like failure load, cracking load, crack propagation, crack pattern, and mi span deflection were examined and compared. Grygo and Lapko [11], presented a study on HSC made of recycled aggregate

concrete. The results were either experimental or nonexperimental showing many positive effects like higher flexural capacity and stiffness under short time loading. Due to advances in technology and the use of HSC, deformation criterion in structural design and the strength of the materials used will not be the only criteria of structural design and other considerations such as elastic stiffness should be taken into account [12]. Importantly, it is impossible to obtain such strength without using special additives and smart concrete mix design. This research aims to experimentally examine the importance of using these additives. Experimental results show importance of materials type, thier porotertis and thier ratio in each concrete mix design in order to have a high quality concerete.

\section{High strength concrete (HSC)}

This study tries to achieve a concrete with compressive strength of $60 \mathrm{MPa}$ and examines the effect of Micro Silica and plasticizer on it. For this purpose, 5 types of mix designs are predicted for each of which 6 concrete samples were considered in order to minimize experimental errors and use the average data.

\subsection{Concrete mix designs with compress length of 60 Mpa}

Concrete mix design is prepared based on Codes ACI 211 and ACI 363 [13],[14] with the following considerations and experimental conditions (see Table1):

Table 1: Type of material used in th study.

\begin{tabular}{c}
\hline Type of Material \\
\hline 28-day compressive \\
strength of concrete \\
Type of cement \\
\\
Density of cement \\
Density of sand \\
Density of gravel \\
Moisture content of fine \\
and coarse aggregate \\
Maximum aggregate \\
diameter \\
Degree of workability
\end{tabular}

Type of used micro silica

Compacting factor

The plasticizer used

Material Properties
$60 \mathrm{MPa}$

Portland cement type II with specific mass of $3.15 \mathrm{gr} / \mathrm{cm}^{3}$, compressive strength of 250

$\mathrm{kg} / \mathrm{cm}^{2}$ and chemical composition of 2.04, 4.95, 21.25 and 64.07 for $\mathrm{SO}_{3}$, $\mathrm{Al}_{2} \mathrm{O}_{3}, \mathrm{SiO}_{2}$ and $\mathrm{CaO}$, respectively $3150 \mathrm{~kg} / \mathrm{m}^{3}$ $2300-2400 \mathrm{~kg} / \mathrm{m}^{3}$ $2600-2500 \mathrm{~kg} / \mathrm{m}^{3}$ 5 and 1 (respectively)

$20 \mathrm{~mm}$;

Very Low

The Micro Silica used is in the form of hydraulic powder composed of $\mathrm{SiO}_{2}$ particles in bright gray color (Figure 1) very low (0.85)

This material is made on PCU basis. It is brown with specific density of 1.1 $\mathrm{kg} / \mathrm{cm}^{3}$
The mix design of interest is performed using a series of experimental graphs known as Erntropy and Shaklock in ACI 363 codes, as follows:

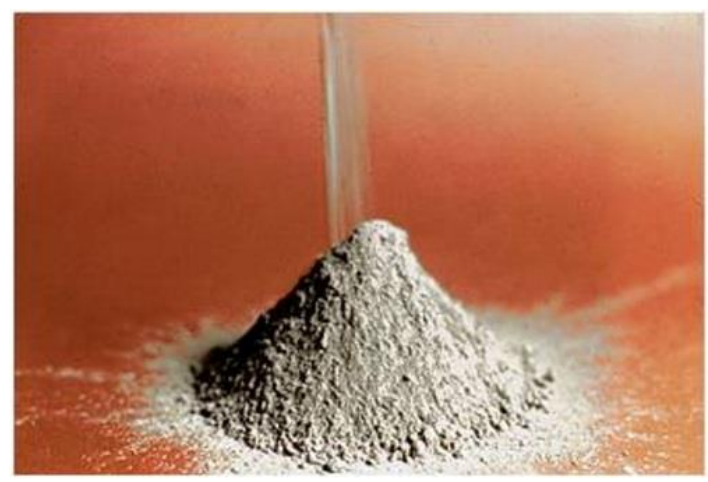

Figure 1: Micro silica used in concrete mix design.

\subsubsection{Reference number assement}

Supposing that 28-day strength is $600 \mathrm{~kg} / \mathrm{cm}^{2}$ and with the suppositions mentioned in section 2.1, Reference Number is obtained using the graph in Figure 2.

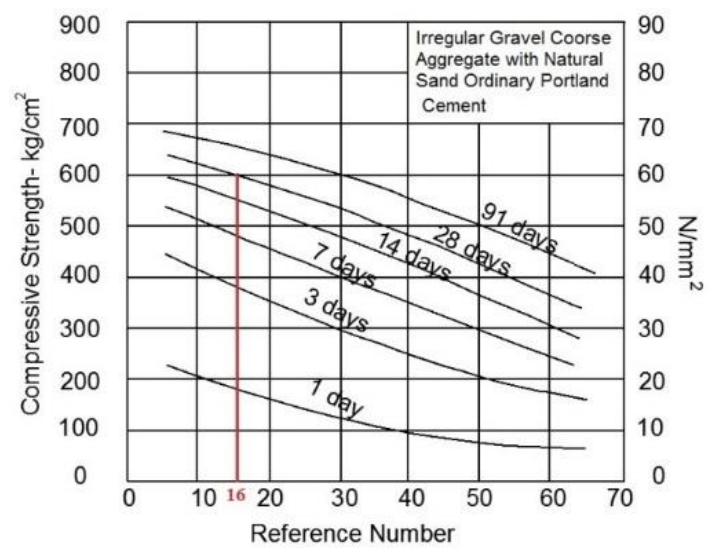

Figure 2: Graph of obtaining reference number [14]. According to graph in Figure 2, Reference Number is equal to 16.

\subsubsection{Water/Cement ratio (W/C) assesment}

According to the value of Reference Number obtained in 2.1.1 and maximum aggregate diameter of $20 \mathrm{~mm}$ and considering the degree of workability to be Very Low, W/C Ratio will be 0.331 (Figure 3).

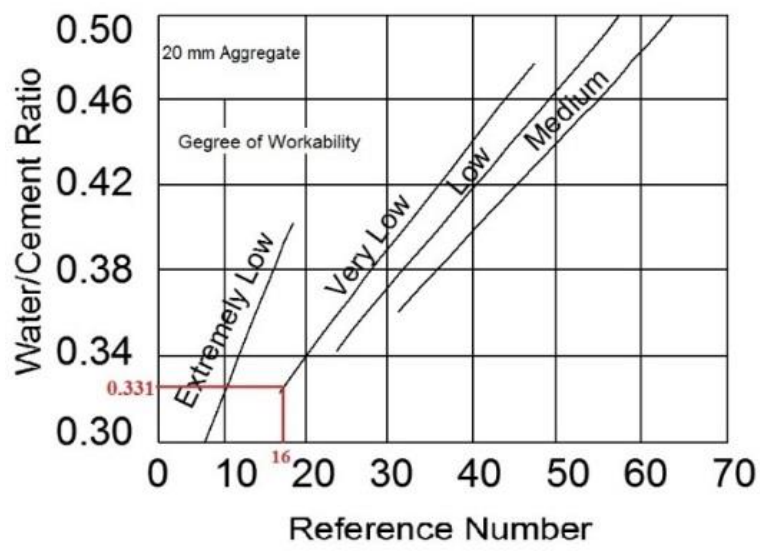

Figure 3: Relation between water/cement ratio and reference number for $200 \mathrm{~mm}$ maximum size aggregates [14]. 


\subsubsection{Aggregate/Cement ratio $(A / C)$ assesment}

The A/C Ratio is obtained based on ACI 363 code. To obtain $\mathrm{A} / \mathrm{C}$ ratio in this Table, the following parameters, obtained in previous steps, are necessary:

- $\quad$ Aggregate material: Irregular Gravel;

- Maximum aggregate diameter: $20 \mathrm{~mm}$;

- $\quad$ Degree of Workability: Very Low;

- Water/Cement Ratio: 0.331.

As a result, A/C Ratio will be 2.9 based on the Table.

\subsubsection{Weight ratio of each aggregate}

The aggregates are combined using the graphical method shown in Figure 4, such that $30 \%$ of aggregates pass through $4.75 \mathrm{~mm}$ IS Sieve.

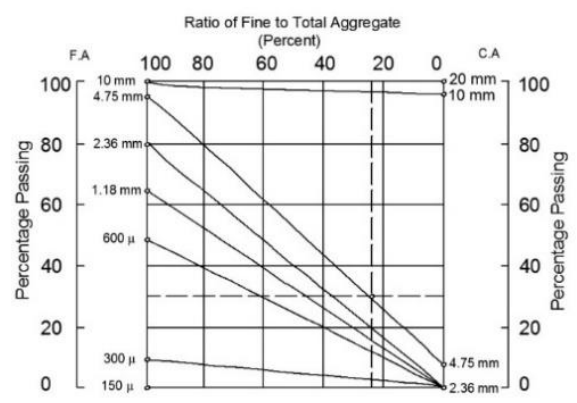

Figure 4: Combining coarse aggregate (C.A) and fine aggregate (F.A).

According to the graph shown in Figure 4 and the existing condition of materials, the weight ratio of each aggregate can be obtained as follows:

C.A/Cement Ratio: 3.15,

F.A/ Cement Ratio: 1.05,

The required ratios are obtained based on dry weight of materials. As a result, concrete mix design of interest is obtained as shown in Table 2. Compressive strength test of the first sample has been shown in the Fisure 5.

Table 2: Concrete mix design of interest.

\begin{tabular}{lccc}
\hline $\begin{array}{c}\text { Weight of } \\
\text { material }\end{array}$ & $\begin{array}{c}\text { In } 1 \mathrm{~m}^{3} \text { of } \\
\text { concrete } \\
(\mathrm{kg})\end{array}$ & $\begin{array}{c}\text { In } 50 \mathrm{~cm}^{3} \text { of } \\
\text { concrete } \\
(\mathrm{kg})\end{array}$ & $\begin{array}{c}\text { In } 60 \mathrm{~cm}^{3} \text { of } \\
\text { concrete } \\
(\mathrm{kg})\end{array}$ \\
$\begin{array}{rccc}\text { Type of } \\
\text { material }\end{array}$ & & 8.95 & 10.75 \\
\hline Cement & 419.3 & 9.40 & 11.28 \\
Sand & 440.2 & 28.20 & 33.83 \\
Gravel & 1320.7 & 3.45 & 4.13 \\
Water & 161.4 & - & - \\
Total weight & 2341.6 & -
\end{tabular}

\subsection{Experimental results of samples}

In this study, 5 types of mix designs are predicted and 6 concrete samples are considered for each of them in order to minimize the experimental errors and use the average data. In the first mix design, the sample is considered with no additives in order to compare the effect of additives in other samples.

When the first sample faced failure; that is, mix design of the first sample could not reach the compressive strength and since the created concrete of this sample was dry and far lower than the required amount in terms of degree of workability, it was concluded that water/cement ratio should be experimentally increased in mix design of the second sample (up to 0.5) to make it compressible and reach the desired degree of workability. However, an increase in water/cement ratio decreases concrete compressive strength [15]. When no results were obtained in the second sample, based on the mix design of the first sample, plasticizer and Micro Silica described in section 2.1 were added to samples 35 and the results were collected. In the third sample, plasticizer with no Micro Silica was used. Finally, in samples 45 , plasticizer with a fixed dose was used by adding Micro Silica with a changing dose. The amount of adding plasticizer should be in terms of a percentage of cement weight and is added to mix design water; the amount of adding Micro Silica should be in terms of cement weight and then combined with cement [16]. Results of all mix designs are presented in Table 3.
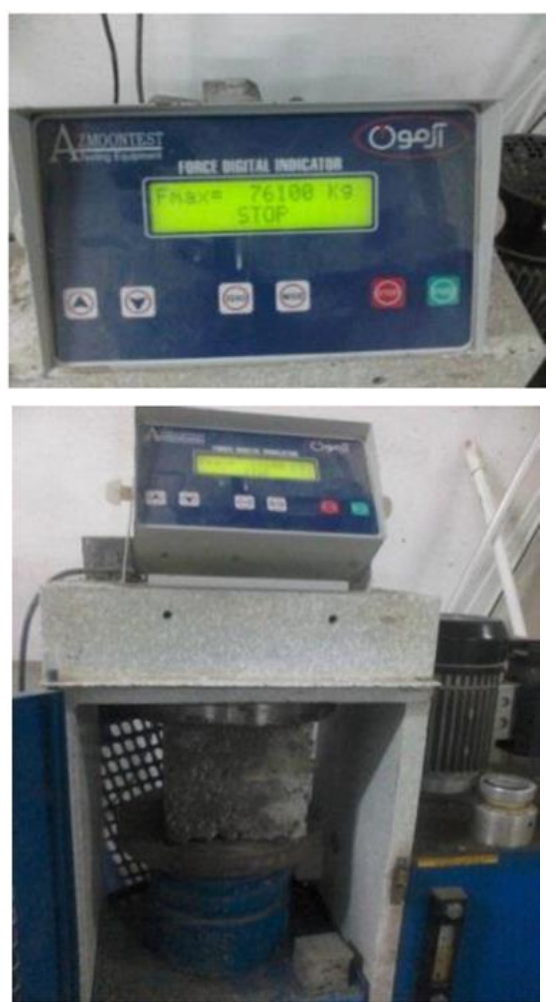

Figure 5: Compressive strength test of the first sample.

\section{Foam concrete}

Concrete is basically a mixture of two components: Aggregates and paste. Light making can be done in both components and has special properties in each part and is performed using different techniques [17].

\subsection{Lightweight cement paste production}

Materials involved in lightweight concrete combination include: cement, sand, lime (depending on the type of foam concrete), entraining materials, water and additives such as Micro Silica, super plasticizers, fly ash, Polypropylene fibers, Plone, etc. However, some types of entraining materials are applicable in lowering concrete water absorption. Chemical entraining or foaming agents are non-recyclable and chloride is used to ensure their stability; notably, chloride can also cause corrosion in contact with steel; therefore, entraining agents containing chloride should not be used in RC and the concrete produced with these materials has no structural application [17]. 
Table 3: Results of compressive strength test of samples.

\begin{tabular}{cccccccccc}
\hline & $\begin{array}{c}\text { Weight of } \\
\text { gravel } \\
(\mathrm{kg})\end{array}$ & $\begin{array}{c}\text { Weight } \\
\text { of sand } \\
(\mathrm{kg})\end{array}$ & $\begin{array}{c}\text { Weight of } \\
\text { water } \\
(\mathrm{kg})\end{array}$ & $\begin{array}{c}\text { Weight of } \\
\text { cement } \\
(\mathrm{kg})\end{array}$ & $\begin{array}{c}\text { Percentage } \\
\text { of } \\
\text { Plasticizer } \\
\text { to cement }\end{array}$ & $\begin{array}{c}\text { Percentage } \\
\text { of Micro } \\
\text { Silica to } \\
\text { cement }\end{array}$ & $\begin{array}{c}\text { 7-day } \\
\text { compressive } \\
\text { strength } \\
(\mathrm{MPa})\end{array}$ & $\begin{array}{c}\text { 28-day } \\
\text { compressive } \\
\text { strength } \\
(\mathrm{MPa})\end{array}$ & $\begin{array}{c}\text { Specific } \\
\text { density of } \\
\text { concrete } \\
\left(\mathrm{Kg} / \mathrm{cm}^{3}\right)\end{array}$ \\
\hline $1^{\text {st }}$ & 1320.7 & 440.2 & 161.4 & 419.3 & - & - & 32.4 & 42.11 & 2456 \\
$2^{\text {nd }}$ & 1320.7 & 440.2 & 188.6 & 419.3 & - & - & 31.8 & 35.03 & 2445 \\
$3^{\text {rd }}$ & 1320.7 & 440.2 & 161.4 & 419.3 & 1.0 & - & 48.4 & 62.92 & 2527 \\
$4^{\text {th }}$ & 1320.7 & 440.2 & 161.4 & 419.3 & 1.0 & 10.0 & 51.6 & 72.20 & 2422.5 \\
$5^{\text {th }}$ & 1320.7 & 440.2 & 161.4 & 419.3 & 1.0 & 15.0 & 39.5 & 55.30 \\
\hline
\end{tabular}

The concrete produced in this way has the following features [18]:

- $\quad$ Reducing specific weight;

- $\quad$ Reducing concrete production cost;

- Increasing concrete slump thereby decreasing W/C Ratio of mix design;

- The possibility of properly forming the concrete surface;

- $\quad$ Easy concrete pumping for story buildings;

- Good frost resistance.

The lightweight concrete produced by this method (foam or aerated concrete), with respect to cement paste porosity and its low strength which leads to decreased strength of the produced concrete, has fewer structural applications and is more used in producing materials with lower loading rates [18].

\subsection{Application of lightweight aggregates}

Lightweight aggregates are aggregates with inner porous space. Some of the lightweight aggregates that are used to produce lightweight concrete are available naturally while others are produced artificially. As the natural aggregates Pumice, Vermiculite and volcanic ash can be mentioned. Artificial aggregates are being made from heating and expansion of materials such as clay. However, Silica-based, fly ash-based, etc. lightweight aggregates are also available which are less applicable than clay lightweight aggregates with respect to the type of raw materials and production method [17]. Due to their specific production condition, lightweight aggregates of this type have special advantages in addition to being light including:

- As an industrial product, it delivers suitable consistent quality,

- It has no mineral limitation like natural lightweight aggregates,

- It lacks harmful materials which may exist in natural lightweight aggregates; its $\mathrm{pH}$ is normal about 7.2,

- It lacks harmful organic matters because it is exposed to more than $1200{ }^{\circ} \mathrm{C}$ temperature; therefore, it has good thermal shock resistance [17],[19].

The concrete produced by this method can have structural application; for this purpose, high-strength cement paste should be used; therefore, Micro Silica and a combination of aggregates and lightweight aggregates are used in order to produce this type of lightweight concrete [16].

\subsection{Description of materials and the performed experiments}

The experiment was performed with different densities in order to determine mechanical and physical properties of foam concretes. The properties of interest including dry and wet specific weight, water absorption, drying-induced shrinkage, and compressive strength are calculated.

\subsubsection{Description of used materials}

- Cement: type II Portland cement,

- Gravel: very small gravel was used in this study,

- Foaming material and foam stabilizer: the foaming material and foam stabilizer were diluted with water with 1:5 ratio.

\subsection{Foam concrete mix design}

Foam concrete mix design was decided based on absolute volume of raw materials for each density. The volume of water hydration was considered as a percentage of cement amount. The amount of cement corresponds to the range recommended in [16]; The cement weight in mix was determined by subtracting cement weight and hydration water from dry density. Through calculating the amount of water mix in order to achieve the desired uniformity as well as cement and gravel density in mix, air-voids and foam volume requirements are determined. In order to examine the effect of various parameters on foam concrete properties, a series of experiments was conducted in this study. The raw material mixture for the production of foam concrete containing cement, water, foam and aggregate (fly gravel, stone powder, etc.) are used in mix design with different amounts in order to achieve volumetric weight and other required specifications. Foam is a protein-based or chemical material with stable foaming property. Stability means that foam maintains its property during mixture and dislocation process and until the initial cementing process thereby leading to formation of pore space inside concrete [16]. The produced foam has been shown in the Figure 6. 


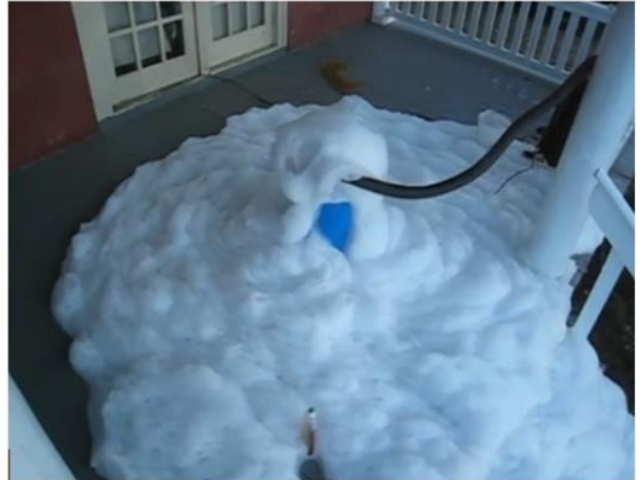

Figure 6: The produced foam.

Chemical foaming agents have lower stability used to produce concretes with higher volumetric weight as well as structural concretes. Moreover, chemical foaming agent has lower durability than the preotein type. The protein-based foam has a more suitable foam durability and quality; however, longterm preservation of its raw materials is impossible. The base material is diluted with water (the mix ratio of foam liquid to water was 1:5) and it is poured in the faom maker machine. in order to produce stable foam. The final product- the foam of interest- should be added to concrete mixture. The most suitable method of mixing foam with concrete is to first make the base concrete containing cement, water and gravel and then add the foaming agent [17].

Table 4: Specifications of three types of foam available in the workshop.

\begin{tabular}{ccl}
\hline $\begin{array}{c}\text { Foam } \\
\text { stability } \\
\text { (min.) }\end{array}$ & $\begin{array}{c}\text { density } \\
\left(\frac{\mathrm{kg}}{\mathrm{m}^{3}}\right)\end{array}$ & \multicolumn{1}{c}{ Type of foam } \\
\hline 60 & 72 & Protein-based foam \\
30 & 48 & Chemical foaming agent-Type I \\
40 & 40 & Chemical foaming agent-Type II \\
\hline
\end{tabular}

In this research, the chemical foaming agent- type II is used to make the laboratory samples.

Table 5: Specifications of the materials used in concrete mix design.

\begin{tabular}{cc}
\hline density $\left(\mathrm{kg} / \mathrm{m}^{3}\right)$ & Materials \\
\hline 3150 & Cement \\
2520 & gravel (fly) \\
2090 & Fly ash \\
2100 & Stone powder \\
40 & Foam \\
\hline
\end{tabular}

In order to perform the experiment, concrete samples of $15 \times 15 \times 15 \mathrm{~cm}^{3}$ dimensions were used, as shown in Figure (7).

\subsection{Water/Cement and gravel ratios in foam concrete specifications}

\subsubsection{Water/Cement ratio assesment}

In general, the amount of water used in this concrete is high and the $\mathrm{W} / \mathrm{C}$ ratio ranges between 0.4-0.7 [17], which is because this concrete contains a high percentage of fine aggregates which increases the amount of water consumption in the mix design. If water content in the mix design is considered to be low, the mixture compensates for its water shortage with the foam, thereby the foam is lost and volumetric weight of concrete increases. Moreover, it should be noted that high percentage of water consumption in the mix design increases concrete shrinkage. In other words, it is very important to control the content of water consumption in foam concrete mix design.

\subsubsection{Gravel/Cement Ratio Assesment}

Generally, only cement and no gravel is used in the mix design in order to obtain low densities of about $300 \mathrm{~kg} / \mathrm{m}^{3}$. For achieving higher densities as well as higher compressive strength, the gravel/cement ratio is increased. Generally, 1, 0.5 and 1.3 ratios (cement/gravel) are used [17]. Cement content used is not lower than $300 \mathrm{~kg} / \mathrm{m}^{3}$ since it leads to sharp drop in the strength. In order to examine the effect of used materials on characteristics of foam concrete, the following experiments were performed by replacing stone powder, fly gravel, fly ash in the mix design.
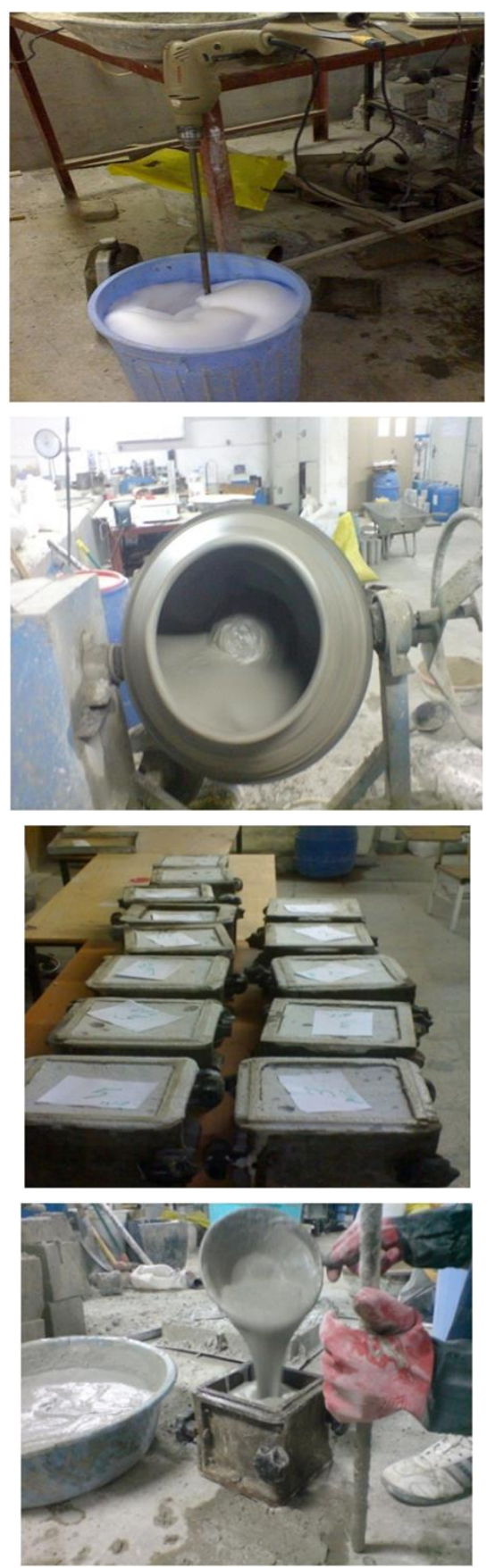

Figure 7: The produced foam concrete samples. 
Table 6: The initial mix design of samples for the foam concrete.

\begin{tabular}{cccccccc}
\hline Sample & $\begin{array}{c}\text { Specific weight of concrete } \\
\left(\mathrm{kg} / \mathrm{m}^{3}\right)\end{array}$ & $\begin{array}{c}\text { Foam } \\
\left(\mathrm{m}^{3}\right)\end{array}$ & $\begin{array}{c}\text { Water } \\
(\mathrm{kg})\end{array}$ & $\begin{array}{c}\text { Fly ash } \\
(\mathrm{kg})\end{array}$ & $\begin{array}{c}\text { Stone powde } \\
(\mathrm{kg})\end{array}$ & $\begin{array}{c}\text { Fly gravel } \\
(\mathrm{kg})\end{array}$ & $\begin{array}{c}\text { Cement } \\
(\mathrm{kg})\end{array}$ \\
\hline 1rst & 620 & 0.5 & 280 & 370 & 400 & 340 & 170 \\
$2^{\text {nd }}$ & 352 & 0.5 & 280 & 300 & 340 & 280 & 170 \\
$3^{\text {rd }}$ & 690 & 0.5 & 280 & 340 & 420 & 300 & 170 \\
\hline
\end{tabular}

Table 7: Mix design in order to improve the strength of samples.

\begin{tabular}{ccccccccc}
\hline NO & $\begin{array}{c}\text { 28-day } \\
\text { strength } \\
\left(\mathrm{kg} / \mathrm{cm}^{2}\right)\end{array}$ & $\begin{array}{c}\text { Specific } \\
\text { weight } \\
\left(\mathrm{kg} / \mathrm{m}^{3}\right)\end{array}$ & $\begin{array}{c}\text { Foam } \\
\left(\mathrm{m}^{3}\right)\end{array}$ & $\begin{array}{c}\text { Water } \\
(\mathrm{kg})\end{array}$ & $\begin{array}{c}\text { Fly ash } \\
(\mathrm{kg})\end{array}$ & $\begin{array}{c}\text { Stone powder } \\
(\mathrm{kg})\end{array}$ & $\begin{array}{c}\text { Fly gravel } \\
(\mathrm{kg})\end{array}$ & $\begin{array}{c}\text { Cement } \\
(\mathrm{kg})\end{array}$ \\
\hline 1rst & 153 & 1340 & $0 / 2$ & 400 & 500 & 800 & 600 & 300 \\
$2^{\text {nd }}$ & 84 & 1150 & $0 / 2$ & 400 & 400 & 600 & 500 & 300 \\
$3^{\text {rd }}$ & 73 & 1410 & $0 / 2$ & 400 & 600 & 700 & 700 & 300 \\
\hline
\end{tabular}

\subsection{A discussion of experimental results}

Shrinkage due to drying of mixtures was determined in form of $15 \times 15 \times 15 \mathrm{~cm}^{3}$. The samples were transferred to normal laboratory condition with relative moisture of $40 \%$ after 28 days of moisturizing. As a matter of fact, some studies conducted on foam concrete [18],[19] restrict the consumption of this material to cases that high shrinkage is not problematic. In coastal areas with no access to clay resources for construction of clay bricks and blocks, transportation costs increase the price of brick and block byproducts by $100 \%$ [20- 23]. However, fly gravel resources abound in these areas, where concrete blocks and panels can be made in these regions using foam concrete which is costefficient. They can also be used in place of aggregated materials for excavation filling in the streets. The former advantage guarantees foam concrete performance in case of its application in sub base level of ways, particularly in regions with no access to suitable aggregated material resource. In addition to the above advantages, with respect to fire resistant property of this type of concrete, it can be used as a fireproof material.

\section{Conclusion}

The experimental results concerning high-strength concrete (HSC) are as follows:

A. In order to increase HSC plasticizer ability, no water can be used; since it highly decreases compressive strength of concrete (compared to the compressive strength of the $1^{\text {st }}$ and $2^{\text {nd }}$ samples),

B. Micro Silica has a positive effect on increasing the compressive strength of concrete. Micro Silica particles contribute to reduction in pore space within concrete aggregates due to their very small diameter, by doing so, they contribute to an increase in the compressive strength of concrete in addition to making the concrete impermeable (compared to the $3^{\text {rd }}$ and $4^{\text {th }}$ samples),

C. In case of using Micro Silica in HSC, super plasticizer should be added to the concrete, because Micro Silica decreases concrete consistency due to its extremely fine particles; since the $\mathrm{W} / \mathrm{C}$ ratio cannot be increased in order to increase efficiency, plasticizer should be added to increase the degree of workability,

D. The dosage of Micro Silica is $10 \%$ of cement weight; as this dosage increases, the strength decreases since cement paste is not properly bonded to the aggregate (comparing the $4^{\text {th }}$ and $5^{\text {th }}$ samples). However, this dosage depends on the Micro Silica manufacturers.

Experimental results about foam concrete:

Compressive strength of foam concrete mixtures is highly influenced by Water/Cement ratio contents. Mixtures with lower water/cement ratio have higher strength in similar densities. Application of coarse gravel, particularly in heavier mixtures, leads to a significant reduction in water/cement ratio. A more suitable performance of these mixtures results in higher compressive strength. Notably, the foam added to the mixtures depends on the consumed volume of foam and its density. Shrinkage due to drying is determined by measuring length of samples at various time intervals. High drying shrinkage of foam concrete is an important aspect which should be taken into account in application of this material.

\section{Reference}

[1] Ramamurthy K, Nambiar EKK, Ranjani GIS. "A classification of studies on properties of foam concrete". Cement and Concrete Composites, 31(6), 388-396, 2009.

[2] Faghihmaleki H, Nejati F, Mirzagoltabar-Roshan A, Batebi-Motlagh Y. "An evaluation of multi-hazard risk subjected to blast and earthquake loads in RC moment frame with shear wall". Journal of Engineering Science \& Technology. In press.

[3] Khaloo A, Masoomi H, Nozhati S, Dehcheshmeh MM. "Influence of diaphragm opening on seismic response of rectangular RC buildings with end shear walls". Journal of Scientia Iranica. In Press.

[4] Nambiar EKK, Ramamurthy K. "Influence of filler type on the properties of foam concrete". Cement and Concrete Composites, 28(5), 475-480. 2006.

[5] Just A, Middendorf B. "Microstructure of high-strength foam concrete". Materials Characterization, 60(7), 741-748, 2009.

[6] Amran YHM, Farzadnia N, Ali AAA. "Properties and applications of foamed concrete; a review". Construction and Building Materials. 101(1), 990-1005, 2015. 
[7] Jianga J, Lua Z, Niua Y, Lia J, Zhanga Y. "Study on the preparation and properties of high-porosity foamed concretes based on ordinary Portland cement". Materials \& Design, 92(15), 949-959, 2015.

[8] Guoa H, Guoa W, Shib Y. "Computational modeling of the mechanical response of lightweight foamed concrete over a wide range of temperatures and strain rates". Construction and Building Materials, 95(2015), 622-631, 2015.

[9] Mousa MI. "Flexural behaviour and ductility of high strength concrete (HSC) beams with tension lap splice". Alexandria Engineering Journal. 54(3). 551-563, 2015.

[10] El-Azab A, Mohamed HM. "Effect of tension lap splice on the behavior of high strength concrete (HSC) beams". HBRC Journal, 10(3), 287-297, 2014.

[11] Lapko A, Grygo R. "Studies of RC Beams Made of Recycling Aggregate Concrete Strengthened with the HSC-HPC Inclusions". Procedia Engineering. 57(2013), 678-686, 2013.

[12] Mehta PK, Monteiro PJM. "CONCRETE Microstructure, Properties and Materials". $3^{\text {rd }}$ ed. New Delhi, India, Central Board of Irrigation and Power, 2002.

[13] ACI Committee 211 (ACI 211.4R-93). "Guide for Selecting Proportions for High-Strength Concrete With Portland Cement and Fly Ash". American Concrete Institute, Detroit, Michigan, USA, 1993.

[14] ACI 363 R-92. "State-of- the art Report on High Strength Concrete, ACI Manual of Concrete Practice". Part-I, American Concrete Institute, USA, 1993.
[15] Aïtcin PC. "The importance of the water-cement and water-binder ratios". Science and Technology of Concrete Admixtures. Pages 3-13, 2016. doi:10.1016/B978-0-08100693-1.00001-1.

[16] Neville AM. Properties of Concrete. $5^{\text {th }}$ ed. Pearson Education Limited, Harlow, United Kingdom, 2011.

[17] Nambiar EKK, Ramamurthy, K. "Fresh state characteristics of foam concrete". Journal of Materials in Civil Engineering, 20(2), 111-117, 2008.

[18] Nambiar EKK, Ramamurthy K. "Models for strength prediction of foam concrete". Materials and Structures, 41(2), 247-254, 2008.

[19] Zhang Z, Provis JL, Reid A, Wang H. “Geopolymer foam concrete: An emerging material for sustainable construction". Construction and Building Materials, 56(15), 113-127, 2014.

[20] Faghihmaleki H, Najafi EK, Aini AH. "Seismic rehabilitation effect in a steel moment frame subjected to tow critical loads". International Journal of Structural Integrity, 8(1), 1 -11, 2017.

[21] Abdollahzadeh GR., Faghihmaleki H. "Seismic-explosion risk-based robustness index of structures". International Journal of Damage Mechanics, DOI: 10.1177/1056789516651919, (First Online).

[22] Faghihmaleki H, Ahmadian F, Roosta H. "The effect of far field and near field earthquakes on the hysteresis energy and relative displacement of steel moment resisting frame structures". Journal of Building Pathology and Rehabilitation, 2(5),1- 9, 2017. 